\title{
Genetic Variability Studies in F2 Segregating Populations for Yield and Its Component Traits in Okra [Abelmoschu sesculentus (L.)Moench]
}

\author{
V.N. Kavya ${ }^{1 *}$, Prakash Kerure ${ }^{2}$, V. Srinivasa ${ }^{3}$, M. Pitchaimuthu ${ }^{4}$, \\ Y. Kantharaj ${ }^{5}$ and B.N. Harish Babu ${ }^{6}$
}

${ }^{1}$ Department of Vegetable Science, $C O H$, Mudigere, ${ }^{2} I C A R-K V K$, Hiriyur, ${ }^{3}$ Department of Vegetable Science, COH, Mudigere and ${ }^{4}$ Division of vegetable crops, ICAR-IIHR, Bengaluru, ${ }^{5}$ Department of PHT, COH, Mudigere, ${ }^{6}$ AICRP on Groundnut, ZAHRS, Hiriyur, India

*Corresponding author

Keywords

Genetic variability,

Heritability,

Genetic advance,

Segregating

populations, Bi-

parental crosses

Article Info

Accepted:

07 March 2019

Available Online:

10 April 2019

\section{A B S T R A C T}

In the present investigation, an attempt has been made to evaluate genetic variability of yield and its contributing traits in $\mathrm{F}_{2}$ segregating populations of three bi-parental crosses viz., IIHR-875 × IIHR-478, IIHR-478 × IIHR-567 and IIHR-604 × IIHR-347 respectively, along with the parents, $F_{1}$ 's and commercial check (Arka Anamika). For growth and yield parameters the estimates of phenotypic variance (PV) was higher compared to genotypic variance $(\mathrm{GV})$ for all the traits in $\mathrm{F}_{2}$ segregating populations of the three bi-parental crosses. Magnitude of PCV and GCV values was high for number of fruits per plant in IIHR-875 $\times$ IIHR-478, plant height and total yield per plant in the bi-parental cross IIHR$478 \times$ IIHR-567, While in the bi-parental cross IIHR-604 $\times$ IIHR-347 recorded high PCV and GCV values were recorded for number of fruits per plant and total yield per plant. High broad sense heritability values were recorded for the traits plant height and total yield per plant in the bi-parental crosses IIHR-478 $\times$ IIHR-567 and IIHR-604 $\times$ IIHR-347 whereas in the bi-parental cross IIHR-875 $\times$ IIHR-478 exhibited high broad sense heritability value for the trait plant height. Thus, there is an ample scope for improving these traits through direct selection.

\section{Introduction}

Okra [Abelmoschus esculentus (L.) Moench] is a prestigious and prize value vegetable crop, which has captured a significant position among vegetables in India. It is especially valued for its tender green fresh delicious fruits, which are used as vegetable. Okra is normally cultivated during summer and rainy seasons and it is an important vegetable crop of the tropics and subtropics of the world and has found its place in India since time immemorial. Okra is significant herbaceous annual crop, having a somatic chromosome number of $2 n=130$ and is considered to be an amphidiploid. It is being an often cross pollinated crop, out crossing occurs to an extent of 4 to 19 per cent with a maximum of 42.2 per cent by insect assisted pollination (Kumar, 2006), which render a 
considerable amount of variability. Okra is being cultivated for its fibrous fruits or pods. It has multiple virtues, where tender fruits are used as vegetable, eaten boiled or in culinary preparations as sliced and fried pieces. It is also used in thickening of soups and gravies because of its high mucilage content. Okra fruits are sliced, sundried, canned and dehydrated for off-season use. Fruits are rich source of iodine which is helpful in curing goiter.

All forms of plant improvement activities through breeding contemplate an eventual boost in genetic potential for yield. Since yield is polygenically controlled and highly influenced by environment, selection based on yield alone is not effective. The breeder while selecting for high yield has to select indirectly through yield associated and highly heritable characters after eliminating environmental components of phenotypic variance. An attempt to improve a character by selection would be futile unless a major portion of variation is of genotypic and quantitative assessment of the population for yield and its contributing characters is necessary. Study of different variability parameter provides a strong basis for selection of desirable genotype for augmentation of yield and other agronomical attributes. Such study estimates the feasibility of using available genetic resources for effective improvement. The $\mathrm{F}_{2}$ generation is critical for success of the breeding programme, as there are remote chances of recovering superior recombinants in advanced generations.

To achieve genetic improvement in yield traits, it is imperative to generate information on variability, its heritable proportion and also interrelationships existing in the breeding material the breeding programme, as there are remote chances of recovering superior recombinants in advanced generations, if proper selection is not exercised. The present study was formulated to quantify the extent of genetic variability available for total yield per plant and its component traits in $\mathrm{F}_{2}$ segregating populations of okra and to estimate the genetic gain that can be made by selection.

\section{Materials and Methods}

The experimental material in the present study consisted of five contrasting parental lines viz., IIHR-875, IIHR-478, IIHR-567, IIHR-604 and IIHR-347. Three crosses were developed by mating the contrasting parent's viz., IIHR-875 × IIHR-478 (C-1), IIHR-478 × IIHR-567 (C-2) and IIHR-604 $\times$ IIHR-347(C$3)$. The $F_{1}$ progeny of these three bi-parental crosses was raised to generate $F_{2}$ populations. The parents and their respective $F_{1}$ 's and $F_{2}$ populations were sown without replication. The parents and hybrids and $\mathrm{F}_{2}$ populations were evaluated in an unreplicated trail and all the recommended package of practices was carried out to grow a successful crop. The experiment was carried out at ICAR-KVK, Babbur farm, Hiriyur (Tq), Chitradurga (Dist.), Karnataka (State) during kharif season of 2017-2018. The observation recorded from five competitive plants per parent and hybrid cross. The mean of these five plants was considered for statistical analysis. With respect to $F_{2}$, observations were recorded on 119 plants in C-1, 224 plants in C-2 and 214 plants in $\mathrm{C}-3$ on the 12 characters viz., plant height $(\mathrm{cm})$, inter-nodal length $(\mathrm{cm})$, branches per plant (No.), stem girth (mm), first fruit producing node, fruit length $(\mathrm{cm})$, fruit diameter $(\mathrm{mm})$ and average fruit weight $(\mathrm{g})$, number of ridges per fruit, number of locules per fruit, number of fruits per plant, total yield per plant (g) as per the NBPGR minimal descriptors. Genotypic and phenotypic coefficient of variation were calculated according to the method suggested by Burton and De-Vane (1953). Heritability in broad 
sense and the genetic advance as percent of mean to visualize the relative utility of genetic gain were worked out as suggested by Johnson et al., (1955).

\section{Results and Discussion}

In okra, the mean values were worked out for 12 quantitative characters in $F_{2}$ segregating populations of the three bi-parental crosses and expressed in Table 1.

The $F_{2}$ segregating populations of the biparental cross IIHR-875 $\times$ IIHR-478 had exhibited higher mean value for fruit yield than other bi-parental crosses. Similarly an increase in the mean values in the bi-parental crossIIHR-875 $\times$ IIHR-478 was also noticed for the traits number of branches per plant (3.64), fruit length (12.82), fruit diameter (12.80), average fruit weight (14.78), number of ridges per fruit (5.02), number of locules per fruit (5.02), number of fruits per plant (18.72) and it has recorded lower mean values for plant height (108.72), inter-nodal length (10.90), stem girth (15.90) and first fruit producing node (4.65). These results were close proximity with the findings of Akinyele and Osekita (2008) and Nwangburuka et al., (2012). Thus, based on mean values it is possible to identify and select the superior segregants for utilization in breeding programme to develop good inbred lines.

For growth and yield parameters the estimates of phenotypic variance (PV) was higher compared to genotypic variance $(\mathrm{GV})$ for all the traits, indicating the role of environmental factors for the expression of these traits in $\mathrm{F}_{2}$ segregating populations of the three biparental crosses. The PCV values were higher than the GCV values for growth and yield related traits in all the three bi-parental crosses. Similar trends were obtained by Rangaiah et al., (1999), Vaid and Singh (1983), Mehta and Zaveri (1999), Kalia and
Padda (1963), Kadlera (1997) and Akinyele and Osekita (2008).

The results on the variability, heritability and genetic advance for 12 characters in okra have been presented in Table 1. For all the characters, the values of phenotypic coefficient of variation (PCV) were higher than the genotypic coefficient of variation (GCV).

\section{Plant height (cm)}

High PCV (22.13, 24.24 and 23.09) values were recorded by the three bi-parental cross derivatives. Bi-parental cross IIHR-478 $\times$ IIHR-567 showed high GCV (23.32) values whereas, other two bi-parental crosses recorded moderate GCV (19.24 and 21.20) values for plant height were reported by Nwangburuka et al., (2012) and Shivaramegowda et al., (2016). High GCV values indicated greater extent of variability present in the character and can be improved through selection. All the bi-parental crosses recorded high broad sense heritability (75.57, 91.30 and 84.33), high GA $(37.67,58.99$ and 48.30) and high GAM (34.65, 45.59 and 39.95) for the trait plant height indicates that the character is governed by additive gene effects and selection may be effective in such cases. These results are in proximity with the earlier findings of Adiger et al., (2011), Nwangburuka et al., (2012), Prakash and Pitchaimuthu (2010) and Prakash et al., (2017).

\section{Inter-nodal length (cm)}

Moderate PCV (16.48, 15.80 and 12.22) values were recorded by all the three biparental cross derivatives. Bi-parental cross IIHR-478 $\times$ IIHR-567 showed moderate GCV (11.01) values whereas, other two bi-parental crosses recorded low GCV (8.70 and 8.66) values for inter-nodal length were reported by 
Gandhi et al., (2001) and Saleem et al., (2018). Three bi-parental crosses exhibited low GA (1.03, 1.76 and 1.46). The bi-parental cross IIHR-875 $\times$ IIHR-478 had shown low heritability coupled with low GAM (9.47) but other two bi-parental crosses exhibited moderate heritability with moderate GAM(15.94 and 12.54) values were reported by Gandhi et al., (2001).

\section{Number of branches per plant}

Moderate PCV (16.93, 16.95 and 16.80) values were exhibited by all the three biparental cross derivatives. Bi-parental crossIIHR-478 $\times$ IIHR-567 showed low GCV (8.72) values whereas, other two bi-parental crosses recorded moderate GCV (11.65 and 10.54) values for number of branches per plant have been reported by Guddadamath et al., (2010), Koundinya et al., (2013), Prakash et al., (2017) and Sravanthi (2017).

The bi-parental cross IIHR-478 $\times$ IIHR-567 recorded low heritability coupled with low GAM values (26.47 and 9.03) but other two bi-parental crosses exhibited moderate heritability (47.37 and 39.39) coupled with moderate GAM (16.23 and 13.39) values indicates that character is governed by nonadditive gene action and hybridization followed by selection would be useful for improving this character. Three bi-parental crosses had low GA values for this character.

\section{Stem girth (mm)}

Bi-parental cross IIHR-875 $\times$ IIHR478showed high PCV (22.06) values whereas, other two bi-parental crosses exhibited moderate PCV (19.80 and 18.74) values. Low GCV (9.28) values recorded by the biparental cross IIHR-604 $\times$ IIHR-347 and other two bi-parental crosses had moderate GCV (10.54 and 13.04) values.
Bi-parental cross IIHR-478 $\times$ IIHR-567 had moderate heritability (43.34) for the trait stem girth whereas, other two bi-parental cross had low heritability (22.84 and 24.52) values for this trait. All the three bi-parental crosses had low GA(1.66, 2.93 and 1.50) values for this character. Low GAM (9.62) exhibited byIIHR-604 $\times$ IIHR-347 and other two biparental crosses had moderate GAM (10.43 and 17.48) values.

\section{First fruit producing node}

Low PCV(9.04) recorded by the bi-parental cross IIHR-478 $\times$ IIHR-567 whereas, other two bi-parental crosses shown moderate PCV (14.93 and 13.90) value for this character. Biparental cross IIHR-604 $\times$ IIHR-347 had exhibited moderate GCV (10.21) values and other two bi-parental crosses recorded low GCV (6.16 and 6.49) values indicates the lack of variability in the tested breeding material.

Low estimates of heritability (17.01) had recorded by the bi-parental cross IIHR-875 $\times$ IIHR-478 but other two bi-parental crosses exhibited moderate heritability (51.46 and 53.92) values. Three bi-parental crosses had low GA $(0.24,0.47$ and 0.72$)$ values for this character. Bi-parental cross IIHR-604 $\times$ IIHR347 had shown moderate GAM (15.52) and other two bi-parental crosses had exhibited low GAM (9.62 and 5.20)

\section{Fruit length (cm)}

Moderate PCV (17.41, 16.57 and 16.60) values were exhibited by all the three biparental cross derivatives were reported by Adeoluwa and Kehinde (2011), Adiger et al., (2011), Gangashetti et al., (2013), Prakash et al., (2017) and Saleem et al., (2018). Biparental cross IIHR-478 $\times$ IIHR-567 had shown low GCV (9.62) values but other two bi-parental crosses exhibited moderate GCV (12.56 and 10.25) values for this character. 
Table.1 Estimates of genetic parameters for growth and yield attributes in F2 segregating generations of the three bi-parental Crosses in Okra (IIHR-875 X IIHR-478, IIHR-478 X IIHR-567, IIHR-604 X IIHR-347)

\begin{tabular}{|c|c|c|c|c|c|c|c|c|c|c|c|c|}
\hline \multirow{2}{*}{$\begin{array}{l}\text { Sl. } \\
\text { No. }\end{array}$} & \multirow[t]{2}{*}{ Characters } & \multirow{2}{*}{$\begin{array}{c}\text { Bi- } \\
\text { parental } \\
\text { crosses }\end{array}$} & \multirow[t]{2}{*}{ Mean } & \multicolumn{2}{|c|}{ Range } & \multirow[t]{2}{*}{ GV } & \multirow[t]{2}{*}{ PV } & \multirow{2}{*}{$\begin{array}{c}\text { GCV } \\
(\%)\end{array}$} & \multirow{2}{*}{$\begin{array}{c}\text { PCV } \\
(\%)\end{array}$} & \multirow{2}{*}{$\begin{array}{c}h^{2} \\
(\%)\end{array}$} & \multirow[t]{2}{*}{ GA } & \multirow{2}{*}{$\begin{array}{c}\text { GAM } \\
(\%)\end{array}$} \\
\hline & & & & Min. & Max. & & & & & & & \\
\hline \multirow[t]{3}{*}{1} & \multirow[t]{3}{*}{ Plant height $(\mathrm{cm})$} & Cross 1 & 108.72 & 65.50 & 175.60 & 437.65 & 579.14 & 19.24 & 22.13 & 75.57 & 37.67 & 34.65 \\
\hline & & Cross 2 & 129.4 & 61.20 & 199.20 & 904.27 & 990.41 & 23.24 & 24.32 & 91.30 & 58.99 & 45.59 \\
\hline & & Cross 3 & 120.9 & 70.10 & 198.20 & 657.13 & 779.28 & 21.20 & 23.09 & 84.33 & 48.30 & 39.95 \\
\hline \multirow[t]{3}{*}{2} & \multirow[t]{3}{*}{ Inter nodal length $(\mathrm{cm})$} & Cross 1 & 10.90 & 7.20 & 15.90 & 0.90 & 3.23 & 8.70 & 16.48 & 27.90 & 1.03 & 9.47 \\
\hline & & Cross 2 & 11.02 & 6.60 & 17.60 & 1.47 & 3.03 & 11.01 & 15.80 & 48.55 & 1.76 & 15.94 \\
\hline & & Cross 3 & 11.66 & 9.10 & 17.20 & 1.02 & 2.03 & 8.66 & 12.22 & 50.22 & 1.46 & 12.54 \\
\hline \multirow[t]{3}{*}{3} & \multirow[t]{3}{*}{ No. of branches per plant } & Cross 1 & 3.64 & 3.00 & 5.00 & 0.18 & 0.38 & 11.65 & 16.93 & 47.37 & 0.59 & 16.23 \\
\hline & & Cross 2 & 3.44 & 2.00 & 5.00 & 0.09 & 0.34 & 8.72 & 16.95 & 26.47 & 0.31 & 9.03 \\
\hline & & Cross 3 & 3.42 & 3.00 & 5.00 & 0.13 & 0.33 & 10.54 & 16.80 & 39.39 & 0.46 & 13.39 \\
\hline \multirow[t]{3}{*}{4} & \multirow[t]{3}{*}{ Stem girth $(\mathrm{mm})$} & Cross 1 & 15.90 & 10.08 & 28.60 & 2.81 & 12.30 & 10.54 & 22.06 & 22.84 & 1.66 & 10.43 \\
\hline & & Cross 2 & 16.77 & 9.64 & 26.75 & 4.78 & 11.03 & 13.04 & 19.80 & 43.34 & 2.93 & 17.48 \\
\hline & & Cross 3 & 15.63 & 10.01 & 24.28 & 2.10 & 8.58 & 9.28 & 18.74 & 24.52 & 1.50 & 9.62 \\
\hline \multirow[t]{3}{*}{5} & \multirow[t]{3}{*}{ First fruit producing node } & Cross 1 & 4.65 & 3.00 & 6.00 & 0.08 & 0.48 & 6.16 & 14.93 & 17.01 & 0.24 & 5.20 \\
\hline & & Cross 2 & 5.02 & 4.00 & 7.00 & 0.11 & 0.21 & 6.49 & 9.04 & 51.46 & 0.47 & 9.42 \\
\hline & & Cross 3 & 4.74 & 3.00 & 6.00 & 0.23 & 0.43 & 10.21 & 13.90 & 53.92 & 0.72 & 15.25 \\
\hline \multirow[t]{3}{*}{6} & \multirow[t]{3}{*}{ Fruit length $(\mathrm{cm})$} & Cross 1 & 12.82 & 10.10 & 19.60 & 2.59 & 4.98 & 12.56 & 17.41 & 52.09 & 2.39 & 18.63 \\
\hline & & Cross 2 & 12.79 & 10.00 & 19.60 & 1.51 & 4.49 & 9.62 & 16.57 & 33.69 & 1.48 & 11.55 \\
\hline & & Cross 3 & 12.11 & 10.00 & 22.10 & 1.54 & 4.04 & 10.25 & 16.60 & 38.12 & 1.57 & 12.99 \\
\hline \multirow[t]{3}{*}{7} & \multirow[t]{3}{*}{ Fruit diameter $(\mathrm{mm})$} & Cross 1 & 12.80 & 10.03 & 19.82 & 2.88 & 5.50 & 13.25 & 18.32 & 52.29 & 2.51 & 19.58 \\
\hline & & Cross 2 & 12.41 & 10.01 & 20.77 & 2.24 & 4.17 & 12.05 & 16.45 & 53.70 & 0.04 & 0.36 \\
\hline & & Cross 3 & 12.27 & 10.10 & 22.00 & 2.08 & 3.34 & 11.76 & 14.89 & 62.39 & 2.35 & 19.15 \\
\hline \multirow[t]{3}{*}{8} & \multirow[t]{3}{*}{ Average fruit weight (g) } & Cross 1 & 14.78 & 10.30 & 27.72 & 4.91 & 13.36 & 14.98 & 24.73 & 36.72 & 2.78 & 18.82 \\
\hline & & Cross 2 & 14.38 & 10.03 & 26.02 & 4.90 & 9.77 & 15.39 & 21.74 & 50.10 & 3.21 & 22.35 \\
\hline & & Cross 3 & 13.72 & 10.30 & 25.67 & 1.73 & 7.60 & 9.58 & 20.09 & 22.72 & 1.30 & 9.50 \\
\hline 9 & No. of ridges per fruit & Cross 1 & 5.02 & 5.00 & 7.00 & 0.32 & 0.42 & 11.27 & 12.91 & 76.19 & 0.31 & 6.24 \\
\hline
\end{tabular}




\begin{tabular}{|c|c|c|c|c|c|c|c|c|c|c|c|c|}
\hline & & Cross 2 & 5.01 & 5.00 & 6.00 & 0.20 & 0.30 & 8.93 & 10.93 & 66.67 & 0.13 & 2.59 \\
\hline & & Cross 3 & 5.01 & 5.00 & 6.00 & 0.04 & 0.14 & 3.99 & 7.47 & 28.57 & 0.07 & 1.31 \\
\hline \multirow[t]{3}{*}{10} & \multirow[t]{3}{*}{ No. of locules per fruit } & Cross 1 & 5.02 & 5.00 & 7.00 & 0.27 & 0.42 & 10.35 & 12.91 & 64.29 & 0.26 & 5.25 \\
\hline & & Cross 2 & 5.01 & 5.00 & 6.00 & 0.10 & 0.20 & 6.31 & 8.93 & 50.00 & 0.09 & 1.85 \\
\hline & & Cross 3 & 5.01 & 5.00 & 6.00 & 0.04 & 0.14 & 3.99 & 7.47 & 28.57 & 0.07 & 1.31 \\
\hline \multirow[t]{3}{*}{11} & \multirow[t]{3}{*}{ No. of fruits per plant } & Cross 1 & 18.72 & 10.00 & 46.00 & 26.08 & 48.78 & 27.28 & 37.31 & 53.46 & 7.62 & 40.71 \\
\hline & & Cross 2 & 17.84 & 10.00 & 41.00 & 7.61 & 32.71 & 15.46 & 32.06 & 23.26 & 2.71 & 15.16 \\
\hline & & Cross 3 & 16.66 & 10.00 & 44.00 & 17.32 & 31.71 & 24.98 & 33.80 & 54.63 & 6.38 & 38.29 \\
\hline \multirow[t]{3}{*}{12} & \multirow[t]{3}{*}{ Total yield per plant $(\mathrm{g})$} & Cross 1 & 315.03 & 107.60 & 1274.97 & 238.83 & 445.10 & 4.91 & 6.70 & 53.66 & 234.67 & 74.49 \\
\hline & & Cross 2 & 279.68 & 120.96 & 1066.91 & 20078.25 & 25170.00 & 50.66 & 56.73 & 79.77 & 261.46 & 93.48 \\
\hline & & Cross 3 & 251.22 & 110.33 & 998.36 & 15880.55 & 22601.12 & 50.10 & 59.76 & 70.26 & 216.78 & 86.18 \\
\hline
\end{tabular}

GV: Genotypic variance, PV: Phenotypic variance, GCV: Genotypic coefficient of variance,

PCV: Phenotypic coefficient of variance, $h^{2}$ (b): Heritability (Broad sense), GA: Genetic advance,

GAM: Genetic advance as per cent mean

Cross 1-IIHR-875 X IIHR-478, Cross 2- IIHR-478 X IIHR-567, Cross 3-IIHR-604 X IIHR-347 
The three bi-parental crosses recorded moderate heritability $(52.09,33.69$ and 38.12), low GA (2.39, 1.48 and 1.57) and moderate GAM (18.63, 11.55 and 12.99) for the trait fruit length have been reported by Bagwale et al., (2016).

\section{Fruit diameter (mm)}

Moderate PCV (18.32, 16.45 and 14.89) and GCV (13.25, 12.05 and 11.76) were recorded by the three bi-parental crosses indicates the role of environment on this character. Similar findings were reported by Guddadamath et al., (2011), Prakash and Pitchaimuthu (2010) and Chandramouli et al., (2016). High broad sense heritability (62.39) exhibited by the biparental cross IIHR-604 × IIHR-347 and other two bi-parental crosses had recorded moderate heritability (52.29 and 53.70) values for this character. Three bi-parental crosses recorded low GAM (2.51, 0.04 and 2.35) values for this character. Bi-parental cross IIHR-478 $\times$ IIHR-567 had shown low GAM (0.361) but other two bi-parental crosses had recorded moderate GAM (19.58 and 19.15) values for fruit diameter were reported by Kandaswamy (2015).

\section{Average fruit weight (g)}

High PCV (24.73, 21.74 and 20.09) values were recorded by the three bi-parental cross derivatives. Bi-parental cross IIHR-604 $\times$ IIHR-347 had shown low GCV (9.58) but other two bi-parental crosses exhibited moderate GCV (14.98 and 15.39) values for average fruit weight were reported by Hazra and Basu (2000). The bi-parental cross IIHR$604 \times$ IIHR-347 had manifested low heritability (22.72) coupled with low GA (1.30) and low GAM (9.50) for this character. Moderate heritability (36.72 and 50.10) coupled with low GA (2.78 and 3.21) and moderate GAM (18.82 and 22.35) was recorded by the other two bi-parental crosses were reported by Guddadamath et al., (2010).

\section{Number of ridges per fruit}

The bi-parental cross IIHR-604 × IIHR-347 had recorded low PCV (7.47) values and other two bi-parental crosses recorded moderate PCV (12.91 and 10.93) values for this character. Moderate GCV (11.27) values exhibited by the bi-parental cross IIHR- $875 \times$ IIHR-478 but other two bi-parental crosses manifested low GCV (8.93 and 3.99) values were reported by Prakash et al., (2017) and Sravanthi (2017). Thebi-parental cross IIHR$604 \times$ IIHR-347 had low heritability (28.57) and other bi-parental crosses shown high broad sense heritability (76.19 and 66.67) values. Three bi-parental crosses exhibited low GA (0.31, 0.13 and 0.007) and GAM $(6.24,2.59$ and 1.31) values for this character. High heritability with low GAM reveals non additive gene action and selection for such traits may not be rewarding. The findings are in agreement with the results of Sharma et al., (2016).

\section{Number of locules per fruit}

Among the bi-parental crosses, the bi-parental cross IIHR-875 $\times$ IIHR-478 had exhibited moderate PCV (12.91) and GCV (10.35) along with high heritability (64.29) coupled with low GA (0.26) and GAM (5.25) values for this character. Low PCV (8.93) and GCV (6.31) along with moderate heritability (50.00) coupled with low GA (0.09) and GAM (1.85) was recorded by the bi-parental cross IIHR-478 $\times$ IIHR-567. The bi-parental crossIIHR-604 $\times$ IIHR-347 had shown low PCV (7.47) and GCV (3.99) along with low heritability (28.57) coupled with low $\mathrm{GA}(0.07)$ and GAM (1.31) values for the character number of locules per fruit.

\section{Number of fruits per plant}

All the bi-parental crosses recorded high PCV (37.31, 32.06 and 33.80) values and the biparental cross IIHR-478 $\times$ IIHR-567 had 
exhibited moderate GCV (15.46) whereas, other two bi-parental crosses manifested high GCV (27.28 and 24.98) values. The difference between PCV and GCV was found to be narrow indicating lesser influence of environment on these characters and presence of more variation in the populations to select superior segregants in the advanced generation. The results obtained on yield and yield related characters in the present study are in agreement with the reports of Yonas et al., (2014), Kandaswamy (2015), Sravanti (2017) and Prakash et al., (2017). Bi-parental cross IIHR-478 $\times$ IIHR-567 had shown low heritability (23.26) coupled with low GA (2.71) and moderate GAM (15.16) and other two bi-parental crosses exhibited moderate heritability(53.46 and 54.63) coupled with low GA (7.62, 2.71 and 6.38) and high GAM (40.71 and 38.29)values.

\section{Total yield per plant}

The bi-parental cross IIHR-875 $\times$ IIHR-478 had shown low PCV(6.70 and 4.91) and GCV values and other bi-parental cross exhibited high PCV (56.73 and 59.76) and GCV (50.66 and 50.10) values for this character. $\mathrm{Bi}$ parental cross IIHR-875 $\times$ IIHR-478 had recorded moderate heritability (53.66) and other two crosses had shown high heritability (79.77 and 70.26). All the bi-parental crosses had shown high GA (234.67, 261.46 and 216.78) and high GAM (74.49, 93.48 and $86.18)$ values for the character.

This indicates additive gene effects, and suggests that effective progress in improvement through selection could be achieved for yield. Similar results were obtained by Prakash and Pitchaimuthu (2010), Guddadamath et al, (2010) Adiger et al., (2011), Gangashetti et al., (2013) and Prakash et al., (2017).

In conclusion, the PCV values were higher than the GCV values for growth and yield related traits in all the three bi-parental crosses. In the $\mathrm{F}_{2}$ population of the bi-parental cross IIHR-875 $\times$ IIHR-478 recorded moderate to high PCV and GCV for all the characters except for days to 50 per cent flowering. Whereas $\mathrm{F}_{2}$ population of the biparental cross IIHR-478 $\times$ IIHR-567 and IIHR-604× IIHR-347 exhibited moderate to high PCV and GCV for all the characters except for days to 50 per cent flowering, number of ridges per fruit and number of locules per fruit. High heritability coupled with high genetic advance as per cent of mean was observed for plant height, number of fruits per plant and total yield per plant in the $\mathrm{F}_{2}$ population of the bi-parental cross IIHR$875 \times$ IIHR-478. Whereas $F_{2}$ population of the bi-parental cross IIHR-478 $\times$ IIHR-567 exhibited high heritability with high genetic advance as per cent of mean for plant height and for total yield per plant. With regard to $F_{2}$ population of the bi-parental cross IIHR-604 $\times$ IIHR-347 high heritability with high genetic advance as per cent of mean was exhibited for plant height and total yield per plant. Thus, there is an ample scope for improving these traits through direct selection.

\section{References}

Ade-Oluwa, O. O. and Kehinde, O. B., 2011, Genetic variability studies in West African okra (Abelmoschus caillei). Agric. Biol. J. North America, 2(10): 1326-1335.

Adiger, S., Shanthkumar, G., Gangashetty, P. I. and Salimath, P. M., 2011, Association studies in okra (Abelmoschus esculentus (L.) Moench). Elect. J. Pl. Breed., 2(4): 568-573.

Akinyele, B. S. and Osekita, O. S., 2008, Correlation and path analysis of seed yield attributes in okra [Abelmoschus esculentus (L.) Moench]. Afr. J. Biotechnol., 5(14): 1330-1336.

Bagwale, S. B., Jawale, L. N., Deosarkar, D.B. and Jadhav, R. A., 2016, Genetic 
variability studies for yield, yield contributing and quality traits in okra [Abelmoschus esculentus (L.) Moench]. Indian J. Agric. Res., 50(6): 614-618.

Burton, G. W. and Devane, R. W., 1953, Estimating heritability in tall foscue (Festuca arubdinaces) from replicated clonal material. Agron. J., 45: 478-481.

Chandramouli, B., Shrihari, D., Rao, A. V. D. D. andRao, P. M., 2016, Studies on genetic variability, heritability and genetic advance in okra [Abelmoschus esculentus(L.) Monech] genotypes. Pl. Archives, 16(2): 679-682.

Gandhi, H. T., Yadav, M. D. and Navale, P. A., 2001, Studies on variability in okra (Abelmoschus esculentus (L.) Moench). J. Maharashtra Agric. Univ., 26(2): 146-148.

Gangashetti, P. I., Laxman, M. and Adiger, S., 2013, Breeding investigations in single and double cross $\mathrm{F}_{4}$ and $\mathrm{F}_{5}$ populations of bhendi (Abelmoschus esculentus (L.) Moench). Molecul.Pl. Breed., 4(12): 96-106.

Guddadamath, S., Mohankumar, H. D., Praveenkumar, B. and Sujatha, K., 2010, Genetic analysis of biparental mating and selfing in segregating populations of Bhendi (Abelmoschus esculentus (L.) Moench). Elect. J. Pl. Breed., 1(6): 1500-1503.

Hazra, P. and Basu, D., 2000, Genetic variability, correlation and path analysis in okra. Ann. Agric. Res., 21(3): 452453.

Johnson, H. W., Robinson, H. F. and Comstock, R. E., 1955, Estimates of genetics and environmental variability in soybeans. Agron.J.,47: 314-318.

Kadlera, D., 1997, Genetic analysis of biparental and selfing progenies for seed yield, oil and other quantitative traits in safflower (Carthamus tinctorius L.). M. Sc. (Agri.) Thesis, Univ. Agril. Sci., Dharwad.
Kalia, A. and Padda., 1963, Studies on biparental progenies in garden pea (Pisum sativum L.). Indian J. Genet. Pl. Breed., 63(1): 79-80.

Kandasamy, R., 2015, Variability studies in okra (Abelmoschus esculentusL.). Asian J. Hort., 10(1): 60-63

Koundinya, A. V. V., Dhankhar, S. K. and Yadav, A. C., 2013, Genetic variability and divergence in okra (Abelmoschus esculentus). Indian J. Agric. Sci., 83(6): 685.

KUMAR, N., 2006, Breeding of Horticultural Crops. New India Publishing Agency, New Delhi, pp. 173-177.

Mehta, D. R. And Zaveri, P. P., 1999, Genetic variability and association analysis in $\mathrm{F}_{5}$ generation resulted from 3 selection scheme in cowpea. J. Maharashtra Agric. Uni., 23: 238-240.

Nwangburuka, C. C., Denton, O. A., Kehinde, Ojo, D. K. and Popoola, A. R., 2012, Genetic variability and heritability in cultivated okra [Abelmoschus esculentus(L.) Moench]. Spanish J. Agric. Res., 10(1): 123-129.

Prakash, K. and Pitchaimuthu, M. and Akshata, H., 2017, Studies on variability, correlation and path analysis of traits contributing to fruit yield and its components in okra (Abelmoschus esculentus (L.) Moench). Elect. J. Pl. Breed., 8(1): 134-141.

Prakash, K. and Pitchaimuthu, M., 2010, Nature and magnitude of genetic variability and diversity studies in okra (Abelmoschus esculentus (L.) Moench). Elect. J. Pl. Breed., 1(6):1426-1430.

Rangaiah, S. and Nehru, S. D., 1999, Genetic variability, correlation and path analysis in cowpea. Karnataka J. Agric. Sci., 11: 927-932.

Saleem, A. M., Amjad, M., Ziaf, K. and Sahi, S. T., 2018, Characterization of okra (Abelmoschus esculentus) genotypes for fruit firmness, other horticultural traits 
and heritability studies. Int. J. Agric. Biol., 20: 345-352.

Sharma, K. P., Mishra, D. P. and Amitpandey, 2016, Genetic variability studies for yield and its contributing traits in okra [Abelmoschus esculentus (L.) Moench]. J. Appl. Nat. Sci., 8(3): 1634-1637.

Shivaramegowda, K. D., Krishnan, A., Jayaramu, Y. K., Kumar, V., Yashoda. andKoh, H., 2016, Genotypic Variation among Okra (Abelmoschus esculentus (L.) Moench) Germplasms in South India. Pl. Breed. Biotechnol., 4(2): 234241.
Sravanthi, U., 2017, Studies on variability, heritability and genetic advance in okra [Abelmoschus esculentus (L.) Moench]. Int. J. Curr. Microbiol. Appl. Sci., 6(10): 1834-1838.

Vaid, I. K. and Singh, K. B., 1993, Genetic variability in $\mathrm{F}_{3}$ and $\mathrm{F}_{4}$ populations of a cross in cowpea. Madras Agric. J., 70:281-283.

Yonas, M., Garedew, W. and Debela, A., 2014, Variability and association of quantitative characters among okra (Abelmoschus esculentus (L.) Moench) collection in South Western Ethiopia. J. Bio. Sci., 14(5): $336-342$.

\section{How to cite this article:}

Kavya, V.N., Prakash Kerure, V. Srinivasa, M. Pitchaimuthu, Y. Kantharaj and Harish Babu, B.N. 2019. Genetic Variability Studies in F2 Segregating Populations for Yield and Its Component Traits in Okra [Abelmoschu sesculentus (L.)Moench]. Int.J.Curr.Microbiol.App.Sci. 8(04): 855-864. doi: https://doi.org/10.20546/ijcmas.2019.804.096 